\title{
New records of lichens and allied fungi from the Leningrad Region, Russia. IV
}

\author{
Dmitry E. Himelbrant ${ }^{1,2}$, Jurga Motiejūnaitè ${ }^{3}$, Juha Pykälä ${ }^{4}$, Ulf Schiefelbein ${ }^{5}$, \\ Irina S. Stepanchikova ${ }^{1,2}$ \\ ${ }^{1}$ Department of Botany, St. Petersburg State University, Universitetskaya emb. 7/9, 199034 St. Petersburg, Russia. \\ E-mails: d_brant@mail.ru, stepa_ir@mail.ru \\ ${ }^{2}$ Laboratory of Lichenology and Bryology, Komarov Botanical Institute RAS, Professor Popov St. 2, \\ 197376 St. Petersburg, Russia. \\ ${ }^{3}$ Laboratory of Mycology, Nature Research Centre, Institute of Botany, Žaliųjų Ežerų 49, LT-08406 Vilnius, Lithuania. \\ E-mail: jurga.motiejunaite@botanika.lt \\ ${ }^{4}$ Finnish Environment Institute, Natural Environment Centre P. O. Box 140, FIN-00251 Helsinki, Finland. \\ E-mail: juha.pykala@ymparisto.fi \\ ${ }^{5}$ Blücherstraße 71, 18055 Rostock, Germany. E-mail: Ulf.Schiefelbein@gmx.de
}

\begin{abstract}
Fourteen species of lichen-forming, fifteen lichenicolous and one non-lichenized calicioid fungus are reported from the Leningrad Region. Tremella coppinsii, Verrucaria cambrini, $V$. fusconigrescens and $V$. nigroumbrina are reported for the first time for Russia; Cheiromycina petri is new to the European Russia; Chaenothecopsis haematopus, Hymenelia epulotica, Muellerella hospitans and Tremella cladoniae are new to the North-Western European Russia; Briancoppinsia cytospora, Cercidospora epipolytropa, Cornutispora lichenicola, Epicladonia simplex, Lichenoconium xanthoriae, Lichenosticta alcicornaria, Phaeopyxis punctum and Syzygospora physciacearum are new to the Leningrad Region. The most noteworthy records are briefly discussed.
\end{abstract}

\section{INTRODUCTION}

This paper continues the series of publications on new records of lichens and allied fungi in the Leningrad Region and Saint-Petersburg (Kuznetsova et al., 2007; Stepanchikova et al., 2009, 2010, 2011a,c; Kuznetsova et al., 2012; Pykälä et al., 2012). Among the 30 taxa listed here, several are reported for the first time in SaintPetersburg, Eastern, Western or the whole Leningrad Region, others are new for the NorthWestern European Russia, European Russia or Russian Federation.

\section{MATERIAL AND METHODS}

The materials of this study were collected mainly in the period of 2005-2012 in the Eastern and Western Leningrad Regions, and Saint-Petersburg (ELR, WLR, SPb respectively) and were deposited in the lichen herbaria of St. Petersburg State University (LECB), Nature Research Centre, Institute of Botany in Vilnius (BILAS), Botanical Museum of University of Helsinki (H), Komarov Botanical Institute in SaintPetersburg (LE) and in the private herbarium of Ulf Schiefelbein (herb. US). Lichenicolous fungi and Cladonia caespiticia were identified by J. Motiejūnaitè, Hymenelia epulotica and Verrucaria fusconigrescens by U. Schiefelbein, $V$. cambrini, $V$. nigroumbrina and $V$. tornensis by J. Pykälä, other lichens by D. Himelbrant and I. Stepanchikova. Lichen substances in the thalli of Cetrelia cetrarioides were analyzed by using the standard technique of high performance thin-layer chromatography (HPTLC) in solvent systems A, B and C (Orange et al., 2001). The illustration of Hymenelia epulotica was made by using a Carl Zeiss STEMI-2000 CS dissecting microscope with an AxioCam ICc 3 camera. Brief discussions on the most interesting records (new to NW European Russia, European Russia or Russian Federation) are included.

The names of the main collectors in the species list are abbreviated as follows: DH - Dmitry E. Himelbrant, IS - Irina S. Stepanchikova. The subdivision of the Leningrad Region (LR) was published in our previous paper (Stepanchikova et al., 2010). North-Western European Russia comprises four regions: Leningrad Region (including Saint-Petersburg), Pskov Region, Novgorod Region and Republic of Karelia (e.g. Andersson et al., 2009). The biogeographical provinces of Eastern Fennoscandia are ab- 
breviated traditionally (Kotiranta et al., 1998): Ik - Isthmus karelicus, Ka - Karelia australis. Lichenicolous fungi are marked with (\#) and non-lichenized fungus with $(+)$. The nomenclature of taxa follows mainly Nordin et al. (2011).

\section{THE SPECIES}

Arthonia BYssacea (Weigel) Almq. - SPb, Petrodvorets District, Oranienbaum, Verkhnij Park, W of Lipovaya alley, 59 $54^{\prime} 51.1^{\prime \prime} \mathrm{N}, 29^{\circ} 44^{\prime} 48.1^{\prime \prime} \mathrm{E}$, old historical park, on bark of old Fraxinus excelsior L., 20.10.2012, leg. DH \& IS (LECB); same locality, between Krasnaya and Lipovaya alleys, $59^{\circ} 54^{\prime} 44.3^{\prime \prime} \mathrm{N}, 29^{\circ} 44^{\prime} 47.9^{\prime \prime} \mathrm{E}$, old historical park, on bark of old Quercus robur L., 20.10.2012, leg. DH \& IS (LECB). - New to SPb. Known from ELR (Stepanchikova et al., 2009) and WLR (Stepanchikova et al., 2011a). Distribution in North-Western European Russia outside of LR: not reported. Distribution in Fennoscandia and Baltic countries: Norway, Sweden, Finland (Nordin et al., 2011), Estonia (Randlane et al., 2012), Latvia (Piterāns, 2001), Lithuania (Motiejūnaitè, 1999). Indicator of biologically valuable forests in the Southern Taiga of North-Western European Russia (Andersson et al., 2009).

\# Briancoppinsia cytospora (Vouaux) Diederich, Ertz, Lawrey \& Van den Boom [syn. Phoma cytospora (Vouaux) D. Hawksw.] - WLR, Kingisepp District, Kurgal'sky protected area, Kurgolovskaya Reima islands, Khangeloda Island, S part, 59 $48^{\prime} 54^{\prime \prime} \mathrm{N}, 28^{\circ} 05^{\prime} 22^{\prime \prime} \mathrm{E}$, seashore, old wooden construction, on thallus of Hypogymnia physodes (L.) Nyl., 14.09.2012, leg. DH \& IS (BILAS). - New to LR. Distribution in North-Western European Russia outside of LR: Republic of Karelia (Fadeeva et al., 2007). Distribution in Fennoscandia and Baltic countries: Norway, Sweden (Nordin et al., 2011), Estonia (Randlane et al., 2012), Latvia (Czarnota \& Kukwa, 2010), Lithuania (Motiejūnaite, 1999).

\# Cercidospora epipolytropa (Mudd) Arnold WLR, Priozersk District, Ik, Smorodinka River Valley, right bank of the Smorodinka River, upper part of the bank, 60²9'26"N, 30 $09^{\prime} 58^{\prime \prime} \mathrm{E}$, margin of a big meadow on the place of a former Finnish village, granite boulder, on thallus of Lecanora intricata (Ach.) Ach., 29.08.2011, leg. IS (BILAS). - New to LR. Distribution in NorthWestern European Russia outside of LR: Repub- lic of Karelia (Fadeeva et al., 2007). Distribution in Fennoscandia and Baltic countries: Norway, Sweden, Finland (Nordin et al., 2011), Estonia (Randlane et al., 2012), Lithuania (Motiejūnaitè et al., 2008).

Cetrelia cetrarioides (Duby) W. L. Culb. et C. F. Culb. - ELR, Tikhvin District, ca. $15 \mathrm{~km}$ SW of Tikhvin, $4 \mathrm{~km} \mathrm{NE}$ of Klinets village, $59^{\circ} 32^{\prime} 34^{\prime \prime} \mathrm{N}, 33^{\circ} 15^{\prime} 15.5^{\prime \prime} \mathrm{E}$, old aspen forest with young spruces and Oxalis acetosella L., on bark of Sorbus aucuparia L., 20.07.2012, leg. IS \& L. V. Gagarina (LECB); ELR, Tikhvin District, Uljanitsa River valley, ca. $3 \mathrm{~km}$ E of Strelkovo and Lavrovo villages, $60^{\circ} 06^{\prime} 39^{\prime \prime} \mathrm{N}, 34^{\circ} 39^{\prime} 19^{\prime \prime} \mathrm{E}$, mixed forest along the brook, on bark of Alnus incana, 25.07.2012, leg. IS \& L. V. Gagarina (LE). Both specimens contain perlatolic acid as a major substance, atranorin and anziaic acid as minor substances. - New to LR. Distribution in North-Western European Russia outside of LR: Republic of Karelia (Fadeeva et al., 2007). Distribution in Fennoscandia and Baltic countries: Norway (Obermayer \& Mayrhofer, 2007), Estonia (Randlane et al., 2012). Probably indicator of biologically valuable forests in the Southern Taiga of North-Western European Russia like Cetrelia olivetorum (Nyl.) W. L. Culb. \& C. F. Culb. (Andersson et al., 2009). This species comprises a part of Cetrelia olivetorum s. lat. complex of chemospecies differing from other species mainly by production of large amounts of perlatolic acid (Obermayer \& Mayrhofer, 2007; Kukwa \& Motiejūnaitè, 2012).

Chaenotheca Chlorella (Ach.) Müll. Arg. - SPb, Petrodvorets District, Oranienbaum, Verkhnij Park, W of Klenovaya alley, 59 $54^{\prime} 51.3^{\prime \prime N}$, $29^{\circ} 44^{\prime} 41.2^{\prime \prime} \mathrm{E}$, old historical park, on bark of old Alnus glutinosa (L.) Gaertn., 20.10.2012, leg. DH \& IS (LECB). - New to SPb. Known from ELR (Stepanchikova et al., 2009) and WLR (Räsänen, 1944; Stepanchikova et al., 2011c). Distribution in North-Western European Russia outside of LR: Republic of Karelia (Fadeeva et al., 2007), Pskov Region (Istomina \& Likhacheva, 2010). Distribution in Fennoscandia and Baltic countries: Norway, Sweden, Finland (Nordin et al., 2011), Estonia (Randlane et al., 2012), Latvia (Piterāns, 2001), Lithuania (Motiejūnaite, 1999). Indicator of biologically valuable forests in the Southern Taiga of North-Western European Russia (Andersson et al., 2009). 
+ Chaenothecopsis haematopus Tibell - ElR, Tikhvin District, ca. $15 \mathrm{~km}$ SW of Tikhvin, $3 \mathrm{~km}$ $\mathrm{NE}$ of Klinets village, 59 $30^{\prime} 27^{\prime \prime} \mathrm{N}, 33^{\circ} 16^{\prime} 23^{\prime \prime} \mathrm{E}$, secondary spruce-aspen forest with Vaccinium myrtillus L. and mosses, on lignum of Populus tremula L., 20.07.2012, leg. IS \& L. V. Gagarina (LE). - New to North-Western European Russia. Known from Republic of Komi and Khabarovsky Krai (Titov, 2006). Distribution in Fennoscandia and Baltic countries: Sweden, Finland (Nordin et al., 2011), Estonia (Randlane et al., 2012). The species is characterized by non-septate pale spores with rounded apices and $\mathrm{K}+$ green reaction of red-pigmented parts of hypothecium and stalk (Titov, 2006).

Cheiromycina Petri D. Hawksw. \& Poelt - ElR, Boksitogorsk District, Kolp' River Valley, ca. $4.5 \mathrm{~km}$ NW of Krasny Bor village, 59 $59^{\prime} 22^{\prime \prime} \mathrm{N}$, $35^{\circ} 08^{\prime} 40^{\prime \prime E}$, old spruce forest with Sphagnum sp., on bark of old Salix caprea L., 29.09.2012, leg. DH \& IS (LECB). - New to European Russia. Known from Sakhalin (Printzen, 2007) and Kamchatka (Himelbrant et al., 2009). Distribution in Fennoscandia and Baltic countries: Estonia (Randlane et al., 2012), Lithuania (Motiejūnaite et al., 2008). Lichenized hyphomycete with bluish-grey sporodochia, slightly enlarged conidiogenous cells and palmately branched multicellular conidia (Printzen, 2007). This species belongs to an indicator genus of biologically valuable forests in the Southern Taiga of North-Western European Russia (Andersson et al., 2009).

Cladonia Caespiticia (Pers.) Flörke - WLR, Vsevolozhsk District, ca. $8 \mathrm{~km}$ SW of Lembolovo, $60^{\circ} 18^{\prime} 58^{\prime \prime} \mathrm{N}, 30^{\circ} 10^{\prime} 32^{\prime \prime} \mathrm{E}$, secondary spruce forest with Vaccinium myrtillus and Sphagnum sp., on lignum of Picea abies (L.) Karst., 09.09.2011, leg. DH \& IS (LECB); WLR, Vsevolozhsk District, ca. $9.5 \mathrm{~km}$ SSW of Lembolovo, $60^{\circ} 17^{\prime} 47^{\prime \prime} \mathrm{N}$, $30^{\circ} 12^{\prime} 03^{\prime \prime E}$, secondary spruce-birch forest with ferns and Oxalis acetosella, on bark of Populus tremula (base of trunk), 15.08.2011, leg. IS (LECB); WLR, Vsevolozhsk District, Smorodinka River Valley, left bank of the Smorodinka River, floodplain, $60^{\circ} 28^{\prime} 40^{\prime \prime} \mathrm{N}, 30^{\circ} 09^{\prime} 04^{\prime \prime} \mathrm{E}$, raised bog with pines and spruces, on lignum of Pinus sylvestris L., 24.08.2011, leg. IS \& G. M. Tagirdzhanova (LECB). - New to WLR. Published for SPb (Zavarzin et al., 1999) on the base of only specimen collected in 19th c. by H. G.
Bongard (LE-L2226) and confirmed by T. Ahti. Distribution in North-Western European Russia outside of LR: not reported. Distribution in Fennoscandia and Baltic countries: Norway, Sweden, Finland (Nordin et al., 2011), Estonia (Randlane et al., 2012), Latvia (Piterāns, 2001), Lithuania (Motiejūnaité, 1999).

\# Cornutispora lichenicola D. Hawksw. \& B. Sutton - WLR, Priozersk District, Ik, Smorodinka River Valley, right bank of the Smorodinka River, upper part of the bank, $60^{\circ} 29^{\prime} 26^{\prime \prime} \mathrm{N}, 30^{\circ} 09^{\prime} 58^{\prime \prime} \mathrm{E}$, margin of a big meadow on place of former Finnish village, granite boulder, on thallus of Parmelia saxatilis (L.) Ach., 29.08.2011, leg. IS (BILAS); ELR, Podporozhje District, $5.5 \mathrm{~km}$ SEE of Vinnitsy, $60^{\circ} 37^{\prime} 41^{\prime \prime} \mathrm{N}, 34^{\circ} 55^{\prime} 14^{\prime \prime} \mathrm{E}$, aspen forest with spruces along the brook, bark of Picea sp., on thallus of Hypogymnia physodes, 20.09.2009, leg. IS (BILAS); ELR, Podporozhje District, 50-100 m S of Chogozero Lake, left bank of the Esipruchej brook, 60 $29^{\prime} 02^{\prime \prime N}$, $35^{\circ} 13^{\prime} 46^{\prime \prime} \mathrm{E}$, swampy pine forest with spruces, bark of Betula sp., on thallus of Cetraria sepincola (Ehrh.) Ach., 22.09.2009, leg. E. S. Kuznetsova \& IS (BILAS). - New to LR. Distribution in North-Western European Russia outside of LR: Republic of Karelia (Fadeeva et al., 2007). Distribution in Fennoscandia and Baltic countries: Norway, Sweden (Nordin et al., 2011), Estonia (Randlane et al., 2012), Lithuania (Motiejūnaitè et al., 2005).

Cyphelium Inquinans (Sm.) Trevis. - SPb, Petrodvorets District, Oranienbaum, Verkhnij Park, between Klenovaya alley and pond, 59 $54^{\prime} 58.5^{\prime \prime} \mathrm{N}$, $29^{\circ} 44^{\prime} 47.8^{\prime \prime} \mathrm{E}$, old historical park, on bark of old Tilia cordata Mill., base of trunk, 20.10.2012, vidi DH \& IS (not collected). - New to SPb. Known from ELR (Kuznetsova et al., 2007) and WLR (Vainio, 1927). All recent records confined to old-growth forests in ELR. Distribution in NorthWestern European Russia outside of LR: Republic of Karelia (Fadeeva et al., 2007). Distribution in Fennoscandia and Baltic countries: Norway, Sweden, Finland (Nordin et al., 2011), Estonia (Randlane et al., 2012), Latvia (Piterāns, 2001), Lithuania (Motiejūnaite et al., 2005). Indicator of biologically valuable forests in the Southern Taiga of North-Western European Russia (Andersson et al., 2009).

\# Epicladonia simplex D. Hawksw. - ElR, Podporozhje District, ca. $13 \mathrm{~km} \mathrm{~W}$ of Ivinsky Razliv 
Lake, NW of Rotmozero Lake, Gladkoe bog, $61^{\circ} 06^{\prime} 35^{\prime \prime} \mathrm{N}, 34^{\circ} 36^{\prime} 23^{\prime \prime} \mathrm{E}$, old aspen-spruce forest with Vaccinium myrtillus and mosses on an island in swamp, on thallus of Cladonia coniocraea (Flörke) Spreng., 05.08.2012, leg. IS \& G. M. Tagirdzhanova (BILAS). - New to LR. Distribution in North-Western European Russia outside of LR: Republic of Karelia (Fadeeva et al., 2007). Distribution in Fennoscandia and Baltic countries: Sweden, Finland (Nordin et al., 2011), Lithuania (Motiejūnaité, 2011).

Hymenelia epulotica (Ach.) Lutzoni - WLR, Ka, Vyborg District, Bolshoj Berezovy Island, $\mathrm{N}$ part of Krasny Ostrov village, $60^{\circ} 19^{\prime} \mathrm{N}, 28^{\circ} 40^{\prime} \mathrm{E}$, near the path, on slate (broken pieces removed from the roof), 13.09.2010, leg. U. Schiefelbein, N. M. Alexeeva \& IS (H, LECB, herb. US; Fig. 1); WLR, Ka, Vyborg District, Vyborg (Viipuri), Vanhaviipuri (old part of town), $60^{\circ} 43^{\prime} \mathrm{N}, 28^{\circ} 45^{\prime} \mathrm{E}$, on littoral granite stones, 05.1875, leg. E. A. Vainio [TUR-V 24965, as additional species to Porpidia macrocarpa (DC.) Hertel \& A. J. Schwab]. - New to North-Western European Russia. Nearest regions in European Russia: Murmansk Region (Urbanavichus et al., 2008) and Republic of Komi (Checklist..., 2003). Distribution in Fennoscandia and Baltic countries: Norway, Sweden, Finland (Nordin et al., 2011), Estonia (Randlane et al., 2012). Hymenelia epulotica is a variable species. The thallus is immersed to epilithic, thin and finely rimose, dirty white, light-brown, grey-brown to grey. The apothecia of studied specimens are $0.2-0.5 \mathrm{~mm}$ in diam., immersed in the thallus, emergent to prominent. The height of hymenium varies from 75 to $120 \mu \mathrm{m}$. The iodine reaction of the hymenium is mostly yellow-green and in some cases redbrown or violet in the upper part but never deep blue. The very similar $H$. rhodopis has a thicker, areolate-cracked thallus and slightly bigger apothecia $(0.4-0.6 \mathrm{~mm})$. H. carnosula differs in the lower hymenium $(<50 \mu \mathrm{m})$, the smaller ascospores $(8-10 \times 5-6 \mu \mathrm{m})$ and the deep blue reaction of the hymenium with iodine solution.

Additional specimens examined: A. Vězda. Lichenes selecti exsiccati, No. 1955 (B 600156442 - Ionaspis epulotica); Austria, G. Lettau, 1907 (B 600189068 - I. epulotica var. crustosa); Austria, Rieber, without year (B 600189027 - I. epulotica var. patellula); Austria, Rieber \& F. Arnold, 1897 (B 600189063 - I. epulotica var. depauperata); Germany, Dr. Rehm (B 600189293 - I. epulotica); Germany, F. Arnold (B 60189072 - I. carnosula); Switzerland, G. Lettau, 1919 (B 600189295
- I. epulotica var. patellula). Examined specimens of Hymenelia carnosula (Arnold) Lutzoni: Germany, G. Lettau, 1895 (B 600189066 - I. epulotica var. depauperata); Germany, F. Arnold, 1860 (B 600189061 - I. epulotica var. minuta). Examined specimens of Hymenelia rhodopis (Sommerf.) Lutzoni: A. Vězda. Lichenes selecti exsiccati, No. 1029 (B 600156443 - I. epulotica var. crustosa); Switzerland: G. Lettau, 1917 (B 600189294); Sweden, A. H. Magnusson, 1921 (B 600189074 - Ionaspis epulotica var. arctica).

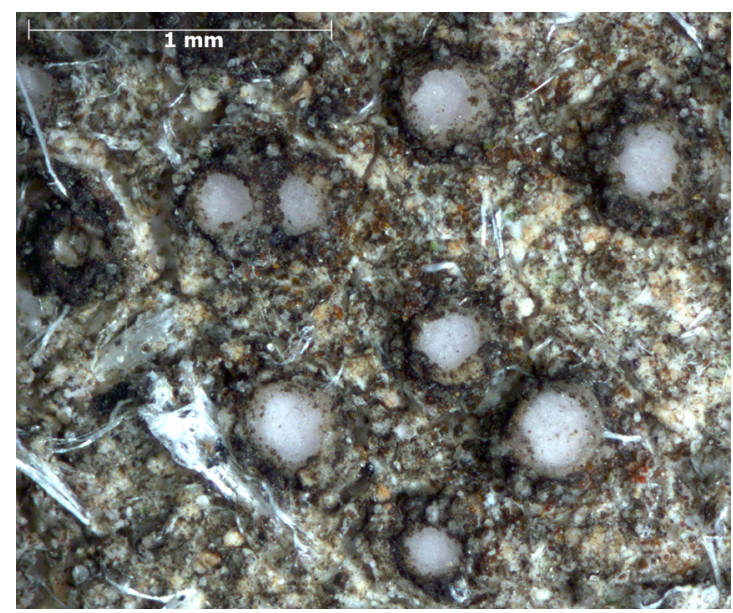

Fig. 1. Hymenelia epulotica, thallus with apothecia.

Lecanactis abietina (Ach.) Körb. - ElR, Tikhvin District, ca. $15 \mathrm{~km}$ SW of Tikhvin, $4 \mathrm{~km} \mathrm{NE}$ of Klinets village, $59^{\circ} 32^{\prime} 37^{\prime \prime} \mathrm{N}, 33^{\circ} 15^{\prime} 12^{\prime \prime} \mathrm{E}$, wet spruce forest with Sphagnum sp. and Vaccinium myrtillus, on bark of Picea sp., 20.07.2012, leg. IS \& L. V. Gagarina (LE). - New to ELR. Previously reported from WLR (Himelbrant \& Andersson, 2008). Distribution in North-Western European Russia outside of LR: Republic of Karelia (Fadeeva et al., 2007), Pskov Region (Istomina \& Likhacheva, 2010). Distribution in Fennoscandia and Baltic countries: Norway, Sweden, Finland (Nordin et al., 2011), Estonia (Randlane et al., 2012), Latvia (Piterāns, 2001), Lithuania (Motiejūnaitè et al., 2004). Indicator of biologically valuable forests in the Southern Taiga of North-Western European Russia (Andersson et al., 2009).

\# Lichenoconium lecanorae (Jaap) D. Hawksw. - ELR, Volkhov District, Zagubsky Peninsula, NW of Zagub'je, S of Storozhno village, along the 
shore of Ladoga Lake, 60²8'46-55"N, $32^{\circ} 36^{\prime} 08_{-}$ $23 " \mathrm{E}$, linden forest with birches, spruces, maples and rowans, bark of Tilia cordata Mill., on thallus of Hypogymnia physodes, 21.05.2011, leg. DH \& E. S. Kuznetsova (BILAS). - New to ELR. Previously reported from WLR (Kuznetsova et al., 2012). Distribution in North-Western European Russia outside of LR: Republic of Karelia (Fadeeva et al., 2007). Distribution in Fennoscandia and Baltic countries: Norway, Sweden, Finland (Nordin et al., 2011), Estonia (Randlane et al., 2012), Lithuania (Motiejūnaitè, 1999).

\# Lichenoconium usneae (Anzi) D. Hawksw. - ELR, Boksitogorsk District, ca. $6 \mathrm{~km} \mathrm{NW}$ of Sidorovo village, $59^{\circ} 57^{\prime} 40^{\prime \prime} \mathrm{N}, 35^{\circ} 00^{\prime} 29^{\prime \prime} \mathrm{E}$, raised bog with pines, bark of Pinus sylvestris, on thallus of Cetraria sepincola, 28.09.2012, leg. DH \& IS (BILAS). - New to ELR. Known from WLR (Alstrup et al., 2005). Distribution in North-Western European Russia outside of LR: Republic of Karelia (Fadeeva et al., 2007). Distribution in Fennoscandia and Baltic countries: Norway, Sweden, Finland (Nordin et al., 2011), Estonia (Randlane et al., 2012), Lithuania (Motiejūnaite, 1999).

\# Lichenoconium Xanthoriae M. S. Christ. $\mathrm{SPb}$, Kurortny District, Sestroretskaya Lowland protected area, central part, $60^{\circ} 07^{\prime} 02^{\prime \prime} \mathrm{N}$, $30^{\circ} 01^{\prime} 52$ 'E, raised bog with pines, bark of Pinus sylvestris, on apothecia of Cetraria sepincola, 11.09.2005, leg. DH, E. S. Kuznetsova \& IS (BILAS); WLR, Kingisepp District, Kurgal'sky protected area, Kurgolovskaya Reima islands, Remisaar Island, central part, 59 $48^{\prime} 33^{\prime \prime} \mathrm{N}$, $28^{\circ} 04^{\prime} 45^{\prime \prime} \mathrm{E}$, lichen-moss wasteland, bark of dead Juniperus communis L., on apothecia of Xanthoria polycarpa (Hoffm.) Th. Fr. ex Rieber, 13.09.2012, leg. DH \& IS (BILAS); same locality, Khangeloda Island, S part, 59 $48^{\prime} 54^{\prime \prime} \mathrm{N}$, $28^{\circ} 05^{\prime} 22^{\prime \prime} \mathrm{E}$, seashore, old wooden construction, on apothecia of $X$. polycarpa, 14.09.2012, leg. DH \& IS (BILAS). - New to LR. Distribution in North-Western European Russia outside of LR: Republic of Karelia (Fadeeva et al., 2007). Distribution in Fennoscandia and Baltic countries: Norway, Sweden, Finland (Nordin et al., 2011), Estonia (Randlane et al., 2012), Lithuania (Motiejūnaitè, 1999).

\# Lichenosticta alcicornaria (Linds.) D. Hawksw. - WLR, Kingisepp District, Kurgal'sky protected area, Kurgal'sky Peninsula, NE of Tiskolovo village, slope of main shore of Narvsky Gulf, $59^{\circ} 43^{\prime} 20^{\prime \prime} \mathrm{N}, 28^{\circ} 02^{\prime} 05^{\prime \prime} \mathrm{E}$, deciduous forest, on squamules of Cladonia sp., 22.11.2009, leg. DH \& IS (BILAS). - New to LR. Distribution in North-Western European Russia outside of LR: Republic of Karelia (Fadeeva et al., 2007). Distribution in Fennoscandia and Baltic countries: Norway, Sweden, Finland (Nordin et al., 2011), Estonia (Randlane et al., 2012), Latvia (Czarnota \& Kukwa, 2010), Lithuania (Motiejūnaitè et al., 2005).

\# Monodictys epilepraria Kukwa \& Diederich - SPb, Kurortny District, Ik, Gladyshevsky protected area, NE part, $\mathrm{N}$ from the railway, $60^{\circ} 13^{\prime} 16^{\prime \prime} \mathrm{N}, 29^{\circ} 31^{\prime} 51^{\prime \prime} \mathrm{E}$, spruce forest with birch, bark of Pinus sylvestris, on thallus of Lepraria jackii Tønsberg, 25.07.2012, leg. DH \& L. V. Kuz'mina (BILAS). - New to SPb. Previously reported from ELR (Stepanchikova et al., 2011a). Distribution in North-Western European Russia outside of LR: not reported. Distribution in Fennoscandia and Baltic countries: Sweden (Nordin et al., 2011), Estonia (Randlane et al., 2012), Latvia (Czarnota \& Kukwa, 2010), Lithuania (Kukwa \& Diederich, 2005).

\# Muellerella hospitans Stizenb. - WLR, Slantsy District, right bank of the Vtroja River (along the border of Pskov Region), 59 $01^{\prime} 08^{\prime \prime} \mathrm{N}$, $27^{\circ} 55^{\prime} 43^{\prime \prime} \mathrm{E}$, mixed forest with broad-leaved trees, bark of Fraxinus excelsior, on apothecia of Bacidia rubella (Hoffm.) A. Massal., 26.09.2009, leg. DH (BILAS); WLR, Kingisepp District, Kurgal'sky protected area, Kurgal'sky Peninsula, $\mathrm{NE}$ of Tiskolovo village, slope of the main shore of Narvsky Gulf, 59 $43^{\prime} 20^{\prime \prime} \mathrm{N}, 28^{\circ} 02^{\prime} 05^{\prime \prime} \mathrm{E}$, deciduous forest, bark of Tilia cordata, on apothecia of B. rubella, 14.04.2007, leg. DH (LECB). - New to North-Western European Russia. Nearest regions in European Russia: Kaliningrad (Dedkov et al., 2007) and Murmansk (Urbanavichus et al., 2008) regions. Distribution in Fennoscandia and Baltic countries: Norway, Sweden, Finland (Nordin et al., 2011), Estonia (Randlane et al., 2012), Latvia (Czarnota \& Kukwa, 2010), Lithuania (Motiejūnaite et al., 2005). This is a common and widespread in the Northern Hemisphere lichenicolous fungus inhabiting apothecia of $B$. rubella and, less commonly, apothecia of other species of Bacidia. It is characterized by polysporous asci and small, globose to subglobose spores (2-4 $\mu \mathrm{m}$ in diam.) (Clauzade et al., 1989). 
Opegrapha niveoatra (Borrer) J. R. Laundon ELR, Tikhvin District, Uljanitsa River Valley, ca. $1 \mathrm{~km}$ SE of Strelkovo village, $60^{\circ} 06^{\prime} 05.5^{\prime \prime} \mathrm{N}$, $34^{\circ} 36^{\prime} 47^{\prime \prime} \mathrm{E}$, mixed forest on slope, bark of Populus tremula, 21.07.2012, IS \& L. V. Gagarina (LE). - New to ELR. Previously reported from WLR (Stepanchikova et al., 2011c). Distribution in North-Western European Russia outside of LR: Republic of Karelia (Fadeeva et al., 2007). Distribution in Fennoscandia and Baltic countries: Norway, Sweden, Finland (Nordin et al., 2011), Estonia (Randlane et al., 2012), Latvia (Piterāns, 2001), Lithuania (Motiejūnaitè, 1999).

\# Phaeopyxis punctum (A. Massal.) Rambold, Triebel \& Coppins - ELR, Podporozhje District, ca. $13 \mathrm{~km} \mathrm{~W}$ of Ivinsky Razliv Lake, NW of Rotmozero Lake, Gladkoe bog, 61 ${ }^{\circ} 06^{\prime} 02^{\prime \prime} \mathrm{N}$, $34^{\circ} 35^{\prime} 27^{\prime \prime} \mathrm{E}$, old pine-aspen-spruce forest with dwarf shrubs and mosses on an island in swamp, bark of Alnus glutinosa, on thallus of Cladonia sp., 04.08.2012, leg. IS \& G. M. Tagirdzhanova (BILAS); ELR, Podporozhje District, ca. $1 \mathrm{~km}$ NW of Tokari village, $61^{\circ} 06^{\prime} 49^{\prime \prime} \mathrm{N}$, $34^{\circ} 23^{\prime} 16^{\prime \prime E}$, old wet spruce forest, bark of Picea sp., on thallus of Cladonia digitata (L.) Hoffm., 28.09.2007, leg. DH \& IS (BILAS); ELR, Podporozhje District, $200 \mathrm{~m} \mathrm{~S}$ of Chogozero Lake, along

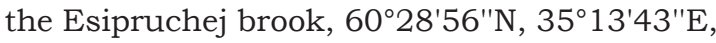
swampy spruce forest with pines, on thallus of C. macilenta Hoffm., 22.09.2009, leg. E. S. Kuznetsova \& IS (BILAS). - New to LR. Distribution in North-Western European Russia outside of LR: Republic of Karelia (Fadeeva et al., 2007). Distribution in Fennoscandia and Baltic countries: Norway, Sweden, Finland (Nordin et al., 2011), Estonia (Randlane et al., 2012), Lithuania (Motiejūnaitè et al., 2011).

SClerophora Pallida (Pers.) Y. J. Yao \& Spooner - $\mathrm{SPb}$, Petrodvorets District, Oranienbaum, Verkhnij Park, W of Lipovaya alley, $59^{\circ} 54^{\prime} 51.1^{\prime \prime} \mathrm{N}, 29^{\circ} 44^{\prime} 48.1^{\prime \prime E}$, old historical park, on bark of old Fraxinus excelsior, 20.10.2012, leg. DH \& IS (LECB). - New to SPb. Known from ELR (Kuznetsova et al., 2007) and WLR (Vainio, 1927). Distribution in North-Western European Russia outside of LR: Pskov Region (Istomina \& Likhacheva, 2010). Distribution in Fennoscandia and Baltic countries: Norway, Sweden, Finland (Nordin et al., 2011), Estonia (Randlane et al., 2012), Latvia (Piterāns, 2001), Lithuania (Motiejūnaitè, 1999). Indicator of bio- logically valuable forests in the Southern Taiga of North-Western European Russia (Andersson et al., 2009).

\# Scutula epiblastematica (Wallr.) Rehm - ELR, Boksitogorsk District, ca. $10 \mathrm{~km} \mathrm{NE}$ of Efimovsky, 59 $32^{\prime} 30^{\prime \prime} \mathrm{N}, 34^{\circ} 50^{\prime} 43^{\prime \prime} \mathrm{E}$, old spruceaspen forest with Vaccinium myrtillus, bark of Populus tremula, on thallus of Peltigera praetextata (Flörke ex Sommerf.) Zopf, 27.09.2012, leg. DH \& IS (BILAS). - New to ELR. Previously reported from WLR (Triebel et al., 1997). Distribution in North-Western European Russia outside of LR: Republic of Karelia (Fadeeva et al., 2007). Distribution in Fennoscandia and Baltic countries: Norway, Sweden, Finland (Nordin et al., 2011), Estonia (Randlane et al., 2012).

\# Syzygospora Physciacearum Diederich - WLR, Priozersk District, Ik, Smorodinka River Valley, right bank of the Smorodinka River, $60^{\circ} 29^{\prime} 07^{\prime \prime} \mathrm{N}$, $30^{\circ} 09^{\prime} 19^{\prime \prime} \mathrm{E}$ and $60^{\circ} 29^{\prime} 07^{\prime \prime} \mathrm{N}, 30^{\circ} 08^{\prime} 08^{\prime \prime} \mathrm{E}$, spruce forest, bark of Populus tremula, on thalli of Physcia aipolia (Ehrh. ex Humb.) Fürnr., 11 and 12.06.2011, leg. IS (BILAS). - New to LR. Distribution in North-Western European Russia outside of LR: Republic of Karelia (Fadeeva et al., 2007). Distribution in Fennoscandia and Baltic countries: Norway, Sweden, Finland (Nordin et al., 2011), Estonia (Randlane et al., 2012), Latvia (Czarnota \& Kukwa, 2010), Lithuania (Motiejūnaite, 1999).

\# Tremella cladoniae Diederich \& M. S. Christ. - WLR, Priozersk District, Ik, Smorodinka River Valley, right bank of the Smorodinka River, $60^{\circ} 29^{\prime} 05^{\prime \prime} \mathrm{N}, 30^{\circ} 08^{\prime} 06^{\prime \prime} \mathrm{E}$, spruce forest with Vaccinium myrtillus, green mosses and Sphagnum sp. patches, bark of Betula sp., on thallus of Cladonia sp., 12.06.2011, leg. IS (LE); same locality, floodplain, $60^{\circ} 27^{\prime} 48^{\prime \prime} \mathrm{N}, 30^{\circ} 11^{\prime} 14^{\prime \prime} \mathrm{E}$, birch forest with young spruces surrounded by meliorative ditches, bark of Betula sp., on thallus of Cladonia coniocraea, 23.08.2011, leg. IS \& G. M. Tagirdzhanova (BILAS); same locality, NW of Parikanjärvi Lake, 60²9'07'N, $30^{\circ} 09^{\prime} 19^{\prime \prime} \mathrm{E}$, spruce forest with $V$. myrtillus and green mosses, bark of Betula sp., on thallus of C. coniocraea, 11.06.2011, leg. IS (BILAS); WLR, Vsevolozhsk District, ca. $8 \mathrm{~km}$ SW of Lembolovo, 60¹8'58'N, 30¹0'32'E, secondary spruce forest with $V$. myrtillus and Sphagnum sp., lignum of Picea abies, on thallus of C. co- 
niocraea, 09.09.2011, leg. DH \& IS (LECB); ELR, Podporozhje District, ca. $13 \mathrm{~km}$ W of Ivinsky Razliv Lake, NW of Rotmozero Lake, Gladkoe bog, $61^{\circ} 06^{\prime} 35^{\prime \prime} \mathrm{N}, 34^{\circ} 36^{\prime} 23^{\prime \prime} \mathrm{E}$, old aspen-spruce forest with $V$. myrtillus and mosses on the island in swamp, bark of Populus tremula, on thallus of C. cornuta (L.) Hoffm., 05.08.2012, leg. IS \& G. M. Tagirdzhanova (BILAS). - New to NorthWestern European Russia. Nearest localities in European Russia: Kaliningrad (Dedkov et al., 2007) and Tula (Zhurbenko \& Gudovicheva, 2013) regions. Distribution in Fennoscandia and Baltic countries: Sweden, Finland (Nordin et al., 2011), Estonia (Randlane et al., 2012), Lithuania (Motiejūnaite, 1999). This widely distributed lichenicolous heterobasidiomycete inhabits various, mainly epiphytic species of Cladonia sect. Cladonia. Macroscopically it is similar to Syzygospora bachmanii, whose basidiomata are usually slightly darker and reddish brown (pinkish brown in T. cladoniae). The structure of basidia [aseptate and with (2-)4 short subuliform epibasidia in S. bachmanii and one-septate, with two cylindrical epibasidia in $T$. cladoniae] and anamorph (lunate and catenate conidia in S. bachmanii and asteroconidia in $T$. cladoniae) are different in these two species (Diederich, 1996). Note: asteroconidia not seen in the specimens kept in BILAS.

\# Tremella coppinsi Diederich \& G. Marson ELR, Podporozhje District, ca. $7 \mathrm{~km}$ W of Ivinsky Razliv Lake, $2.5 \mathrm{~km}$ NE of Rotmozero Lake, $61^{\circ} 06^{\prime} 16^{\prime \prime} \mathrm{N}, 34^{\circ} 42^{\prime} 09^{\prime} \mathrm{E}$, old spruce forest with aspen, dry branches of Picea sp., on thallus of Platismatia glauca (L.) W. L. Culb. et C. F. Culb., 30.09.2008, leg. DH \& IS (BILAS); ELR, Podporozhje District, ca. $11 \mathrm{~km} \mathrm{NE}$ from Vazhiny, along the Krasivy stream, $60^{\circ} 03^{\prime} 53^{\prime \prime} \mathrm{N}, 34^{\circ} 00^{\prime} 44.5^{\prime \prime} \mathrm{E}$, spruce forest with birch and aspen, Vaccinium myrtillus, Oxalis acetosella and green mosses, bark of Picea sp. and Sorbus aucuparia, on thalli of P. glauca, 29.09.2010, leg. DH \& IS (BILAS). - New to Russia. Distribution in Fennoscandia and Baltic countries: Norway, Sweden (Nordin et al., 2011), Estonia (Randlane et al., 2012). T. coppinsii is known from various countries of Europe and from Asia. It inhabits lichens of the genus Platismatia and is characterized by reddish, applanate to pulvinate basidiomata and production of asteroconidia in mature specimens (Diederich, 1996). Asteroconidia were not present in the specimens from ELR, probably because the basidiomata were not mature yet, but typical basidiomata and presence of subsphaerical to ellipsoid, 2-3-celled 8-11.5 x 6-10 $\mu \mathrm{m}$ basidia with longitudinal septa allowed to identify the fungus. Diederich (1996) describes basidia as 2-4-celled, but no 4-celled basidia were observed in our specimens.

VERRUCARIA CAMBRINI Servít - SPb, Kurortny District, Ik, Vicinity of Zelenogorsk, W from protected territory "Schuch'e Lake» (Haukijärvi), $60^{\circ} 13^{\prime} 21^{\prime \prime} \mathrm{N}, 29^{\circ} 44^{\prime} 30^{\prime \prime} \mathrm{E}$, near the road, on concrete, slate and granite covered with concrete, 24.09.2008, leg. DH \& IS (H, LE). - New to Russia. Distribution in Fennoscandia and Baltic countries: Finland (Pykälä, 2013). For the description see Pykälä (2013).

VERRUCARIA FUSCONIGRESCENS Nyl. - WLR, Vyborg District, Ka, Bol'shoj Berezovy Island, cape Lapchaty, $60^{\circ} 17^{\prime} 30^{\prime \prime} \mathrm{N}, 28^{\circ} 33^{\prime} 46^{\prime \prime} \mathrm{E}$, littoral meadow, on granite boulder, 16.09.2010, leg. \& det. US, conf. A. Orange (herb. US). - New to Russia. Distribution in Fennoscandia and Baltic countries: Sweden (Nordin et al., 2011), Finland (Pykälä, 2007). According to Orange et al. (2009), the species is characterized by the well-developed dark brown thallus on the black prothallus, the absence of thalline layer over the perithecia, more or less conical invollucrellum and medium-sized ascospores. The specimen presented here differs in the dark brown prothallus. V. fusconigrescens seems to be restricted to coastal areas (Orange et al., 2009).

Verrucaria nigroumbrina Servit - SPb, Petrodvorets District, Peterhof, Nizhnij park, Zolotaya Gorka fountain, $59^{\circ} 53^{\prime} 14^{\prime \prime} \mathrm{N}, 2^{\circ} 53^{\prime} 50^{\prime \prime} \mathrm{E}$, on concrete $(\mathrm{H})$. - New to Russia. Distribution in Fennoscandia and Baltic countries: Finland (Pykälä, 2011). For the description see Pykälä (2011).

VerruCaria tornensis H. Magn. - SPb, Kurortny District, Ik, Serovsky Ustup projected protected area, ca. $100 \mathrm{~m}$ SW from bridge over the Ushkovsky brook, near road, $60^{\circ} 13^{\prime} 08^{\prime \prime} \mathrm{N}$, $29^{\circ} 36^{\prime} 38.5^{\prime \prime} \mathrm{E}$, on concrete, 06.06.2010, leg. DH, E. S. Kuznetsova \& IS (H). - New to SPb. Recently reported from WLR as new to Russia (Pykälä et al., 2012). Distribution in Fennoscandia and Baltic countries: Sweden, Finland (Nordin et al., 2011). 


\section{ACKNOWLEDGEMENTS}

We would like to thank our colleagues at the Botanical Museum of University of Helsinki and lichen herbarium of University of Turku for their help during our investigations in $\mathrm{H}$ and TUR. The authors also appreciate the help of all the colleagues who participated in the field trips in 2005-2012. Our warm thanks are also due to A. Orange (Cardiff) for revision of Verrucaria fusconigrescens and to H. J. M. Sipman (Berlin) for loan of Hymenelia specimens. We are grateful to Ave Suija (Tartu) who reviewed our manuscript and Tiina Randlane (Tartu) for valuable corrections and recommendations. We wish to express our sincere gratitude to Eliezer Gurarie (Washington) and Olga Gurova (Saint-Petersburg) for linguistic revision. We are grateful to the staff of Metsäliitto Podporozh'e, International Paper and StrojLes-2 (Mayr-Melnhof Holz Efimovskij) corporations for organizing the field trips to different districts of ELR, and Baltic Fund for Nature for organizing the field trip to Kurgolovskaya Reima islands. The study was financially supported by the Russian Foundation for Basic Research (grant 11-04-00901).

\section{REFERENCES}

Alstrup, V., Zavarzin, A. A., Kocourková, J., Kravchenko, A. V., Fadeeva, M. A. \& Schiefelbein, U. 2005. Lichens and lichenicolous fungi found in Northern Ladoga area (Republic of Karelia) during the international fieldtrip in august 2004, prior to the Fifth congress of international lichenological association. Biogeography of Karelia. Proceedings of KarRC RAS. Series Biology 7: 3-16. (In Russian).

Andersson, L., Alexeeva, N. \& Kuznetsova, E. (eds). 2009. Survey of biologically valuable forests in North-Western European Russia. Vol. 2. Identification manual of species to be used during survey at stand level. St. Petersburg. 258 pp. (In Russian).

Checklist for the lichen-forming and lichenicolous fungi of the European northeast of Russia (Komi Republic and Nenetskij National Okrug). 2003. Ver. October 2, 2003 - http:/ /ib.komisc.ru/add/ old/t/ru/os/arx/checklist.html\#I

Clauzade, G., Diederich, P. \& Roux, C. 1989. Nelikenigintaj fungoj likenlogaj. Ilustrita determinlibro. Bulletin de la Societe Linneenne de Provence, Numero Special 1: 1-142.

Czarnota, P. \& Kukwa, M. 2010. New and noteworthy lichenized and lichenicolous fungi from Latvia. Botanica Lithuanica 16(1): 21-27.

Dedkov, V. P., Andreev, M. P. \& Petrenko, D. E. 2007. Annotated list of lichens of Kaliningrad Region. Biodiversity of Kaliningrad Region. Part 1. Fungi, lichens, club-mosses, horsetails and ferns of Kaliningrad Region. Kaliningrad. 79-178. (In Russian).

Diederich, P. 1996. The Lichenicolous Heterobasidiomycetes. Bibliotheca Lichenologica 61: 1-198.

Fadeeva, M. A., Golubkova, N. S., Vitikainen, O. \& Ahti, T. 2007. Conspectus of lichens and lichenicolous fungi of the Republic of Karelia. Karelian Research Centre of RAS, Petrozavodsk. 194 pp. (In Russian, English summary).

Himelbrant D. E. \& Andersson L. 2008. Lichens of biologically valuable territory Kurgal'sky Peninsula, Leningrad Region. XVII Symposium of the Baltic Mycologists and Lichenologists. Estonia, Saaremaa, Mändjala, 17-21 September 2008. Tartu. 19-20.

Himelbrant, D. E., Stepanchikova, I. S. \& Kuznetsova, E. S. 2009. Lichens of some shrubs and dwarf shrubs of Kamchatka Peninsula. Novitates Systematicae Plantarum Non Vascularum 43: 150-171. (In Russian, English summary).

Istomina, N. B. \& Likhacheva, O. V. 2010. Preliminary list of lichens of the Pskov Region. Novitates Systematicae Plantarum Non Vascularum 44: 171-199. (In Russian, English summary).

Kotiranta, H., Uotila, P., Sulkava, S. \& Peltonen, S.-L. (eds). 1998. Red Data Book of East Fennoscandia. Helsinki. 351 pp.

Kukwa, M. \& Diederich, P. 2005. Monodictys epilepraria, a new species of lichenicolous hyphomycetes on Lepraria. The Lichenologist 37(3): 217-220. http://dx.doi.org/10.1017/ S002428290501491X

Kukwa, M. \& Motiejūnaitè, J. 2012. Revision of the lichen genera Cetrelia and Punctelia (Lecanorales, Ascomycota) in Lithuania with implications for their conservation. Herzogia 25(1): 5-14.

Kuznetsova, E., Ahti, T. \& Himelbrant, D. 2007. Lichens and allied fungi of the Eastern Leningrad Region. Norrlinia 16: 1-62.

Kuznetsova, E. S., Motiejūnaitè, J., Stepanchikova, I. S., Himelbrant, D. E. \& Czarnota, P. 2012. New records of lichens and allied fungi from the Leningrad Region, Russia. III. Folia Cryptogamica Estonica 49: 31-37.

Motiejūnaitè, J. 1999. Checklist of lichens and allied fungi of Lithuania. Botanica Lithuanica 5(3): 251-269.

Motiejūnaitè, J. 2011. Lichens and allied fungi from Kamanos State Strict Nature Reserve (northern Lithuania). Botanica Lithuanica 17(2-3): 109-116.

Motiejūnaite, J., Alstrup, V., Randlane, T., Himelbrant, D., Stončius, D., Hermansson, J., Urbanavichus, G., Suija, A., Fritz, Ö., Prigodina Lukošienè, I. \& Johansson, P. 2008. New or noteworthy lichens, lichenicolous and allied fungi from Biržai district, Lithuania. Botanica Lithuanica 14(1): 29-42.

Motiejūnaitè, J., Brackel, W., Stončius, D. \& Preikša, Ž. 2011. Contribution to the Lithuanian flora of lichens and allied fungi. III. Botanica Lithuanica 17(1): 39-46. 
Motiejūnaitė, J., Czyzewska, K. \& Cieslinski, S. 2004. Lichens - indicators of old-growth forests in biocentres of Lithuania and north-east Poland. Botanica Lithuanica 10(1): 59-74.

Motiejūnaitè, J., Stončius, D. \& Kukwa, M. 2005. Contribution to the Lithuanian flora of lichens and allied fungi. II. Botanica Lithuanica 11(1): 41-49.

Nordin, A., Moberg, R., Tønsberg, T., Vitikainen, O., Dalsätt, Å., Myrdal, M., Snitting, D. \& Ekman, S. 2011. Santesson's Checklist of Fennoscandian Lichen-forming and Lichenicolous Fungi. Ver. April 29, 2011 - http://130.238.83.220/santesson/ home.php (30 March 2013).

Obermayer, W. \& Mayrhofer, H. 2007. Hunting for Cetrelia chicitae (Lichenized Ascomycetes) in the Eastern European Alps. Phyton 47(1-2): 231-290.

Orange, A., Hawskworth, D. L., McCarthy, P. M. \& Fletcher, A. 2009. Verrucaria Schrad. (1794). In: Smith, C. W., Aptroot, A., Coppins, B. J., Fletcher, A., Gilbert, O. L., James, P. W. \& Wolseley, P. A. (eds). The lichens of Great Britain and Ireland. The British Lichen Society, London. 931-957.

Orange, A., James, P. W. \& White, F. J. 2001. Microchemical methods for the identification of lichens. British Lichen Society, London. 101 pp.

Piterāns, A. 2001. Checklist of the lichens of Latvia. Latvijas Veǵetācila 3: 5-46.

Printzen, C. 2007. New records of Cheiromycina species, a genus of lichenized hyphomycetes, with $C$. reimeri sp. nov. and a revised key to the species. Nova Hedwigia 84(1-2): 261-267. http://dx.doi. org/10.1127/0029-5035/2007/0084-0261

Pykälä, J. 2007. Additions to the lichen flora of Finland. II. Calcareous rocks and associated soils in Lohja. Graphis Scripta 19: 17-32.

Pykälä, J. 2011. Additions to the lichen flora of Finland. VI. Graphis Scripta 23: 47-55.

Pykälä, J. 2013. Additions to the lichen flora of Finland. VII. Graphis Scripta 25: 21-29.

Pykälä, J., Stepanchikova, I. S., Himelbrant, D. E., Kuznetsova, E. S. \& Alexeeva, N. M. 2012. The lichen genera Thelidium and Verrucaria in the Leningrad Region (Russia). Folia Cryptogamica Estonica 49: 45-57.

Randlane, T., Saag, A. \& Suija, A. 2012. Lichenized, lichenicolous and allied fungi of Estonia. Ver. December 28, 2012 - http://esamba.bo.bg.ut.ee/ checklist/est/home.php (20 March 2013).

Räsänen, V. 1944. Eine Pflanzenexkursion zu der Klosterinsel Konevitsa im westlichen Teil des Laatokka-See. Annales Botanici Societatis Zoologicae-Botanicae Fennicae "Vanamo» 20(15): 53-64.
Stepanchikova, I. S., Himelbrant, D. E., Kukwa, M. \& Kuznetsova, E. S. 2011a. New records of lichens and allied fungi from the Leningrad Region, Russia. II. Folia Cryptogamica Estonica 48: 85-94.

Stepanchikova, I. S., Kukwa, M., Kuznetsova, E. S., Motiejūnaitè, J. \& Himelbrant, D. E. 2010. New records of lichens and allied fungi from the Leningrad Region. Folia Cryptogamica Estonica 47: 77-84.

Stepanchikova, I. S., Kukwa, M., Notov, A. A. \& Himelbrant, D. E. 2011b. New data on the lichen flora of Tver' Region. Vestnik Tverskogo Gosudarstvennogo Universiteta, Series Biology and Ecology 23(20): 137-142. (In Russian, English summary).

Stepanchikova, I. S., Schiefelbein, U., Alexeeva, N. M., Ahti, T., Kukwa, M., Himelbrant, D. E. \& Pykälä, J. 2011c. Additions to the lichen biota of Berezovye Islands, Leningrad Region, Russia. Folia Cryptogamica Estonica 48: 95-106.

Titov, A. N. 2006. Mycocalicioid fungi (the order Mycocaliciales) in Holarctic. Moscow. 296 pp. (In Russian, English summary).

Triebel, D., Wedin, M. \& Rambold, G. 1997. The genus Scutula (lichenicolous ascomycetes, Lecanorales): species on the Peltigera canina and $P$. horizontalis groups. Acta Universitatis Upsaliensis. Symbolae Botanicae Upsalienses 32(1): 323-337.

Urbanavichus, G., Ahti, T. \& Urbanavichene, I. 2008. Catalogue of lichens and allied fungi of Murmansk Region, Russia. Norrlinia 17: 1-80.

Vainio, E. A. 1927. Lichenographia Fennica. III. Coniocarpineae. Acta Societatis pro Fauna et Flora Fennica 57(1): 1-138.

Zavarzin, A. A., Katenina, O. A., Kotlov, Yu. V. \& Sokolova, S. V. 1999. Lichens of St. Petersburg and Leningrad Region. In: Biodiversity of the Leningrad Region (Algae. Fungi. Lichens. Bryophytes. Invertebrates. Fishes and pisciformes). Transactions of St. Petersburg Naturalists Society. Series 6. Vol. 2: 205-260. (In Russian, English summary).

Zhurbenko, M. P. \& Gudovicheva, A. V. 2013. Zwackhiomyces echinulatus and other lichenicolous fungi from Tula Region of Russia. Mycology and Phytopathology 47(1): 19-20. (In Russian, English summary). 
32 Folia Cryptog. Estonica 